\title{
Isozyme variation in four species of the Simulium perflavum species group (Diptera: Simuliidae) from the Brazilian Amazon
}

\author{
Vera Margarete Scarpassa and Neusa Hamada \\ Coordenação de Pesquisas em Entomologia, Instituto Nacional de Pesquisas da Amazônia, \\ Manaus, Amazonas, Brazil.
}

\begin{abstract}
Electrophoretic studies of isozymes were done with four closely related species of the Simulium perflavum species group (Diptera: Simuliidade) in the Brazilian Amazon, using last-instar larvae collected in the field. Ten enzymes were studied, which yielded 11 loci. Diagnostic loci were not found between Simulium maroniense cytotype D and Simulium rorotaense. Simulium maroniense and $S$. rorotaense differed from Simulium trombetense by two diagnostic loci ( $M e$ and $X d h$ ), and Simulium perflavum differed from the other three species by four diagnostic loci (Me, Xdh, Mdh, and Got). The mean number of alleles per locus ranged from 1.30 to 2.30, the percentage of polymorphic loci ranged from 18.2 to $63.6 \%$ and the mean heterozygosity values observed ranged from 0.062 to 0.108 . Genetic distances among the species ranged from 0.010 to 0.581 . The lowest value was obtained between $S$. maroniense and S. rorotaense, and the highest between S. perflavum and S. trombetense. The genetic relationships among the four $S$. perflavum group species indicate that they are closely related. The high similarity at the isozyme level, allied to previous studies of morphology and polytene chromosomes, may suggest that the divergence time since the separation of $S$. maroniense and $S$. rorotaense is still too recent for diagnostic loci to have evolved.
\end{abstract}

Key words: Simulium perflavum species group, isozymes, genetic divergence, biochemical systematic, Brazilian Amazon.

Received: June 12, 2002; accepted: December 18, 2002.

\section{Introduction}

Enzymatic markers are helpful tools for estimating genetic variability and gene flow among populations and for distinguishing closely related and/or sibling species in different animal groups, especially insects (Steiner et al., 1982; Kreutzer et al., 1990; Farid et al., 1991; Tabachnick, 1992; Krafsur et al., 1993; Lopes and Moreno, 1995; Almeida and Sodré, 1998). In the genus Simulium, several species have been studied using these markers (May et al. 1977; Petersen, 1982; Snyder, 1982; Snyder and Linton, 1983; Mebrahtu et al., 1987; Charalambous et al., 1993; Davies et al., 2000). However, relatively few loci were interpreted in most of the studies (Mebrahtu et al., 1987; Charalambous et al., 1993; Davies et al., 2000).

The Simulium perflavum species group is distributed in South America from the non-Andean northern to northern Argentina. Systematic studies on this species group are controversial, with the number of species believed to exist varying from four to seven due to high similarity at the mor-

Send correspondence to Vera Margarete Scarpassa. CPEN, Instituto Nacional de Pesquisas da Amazônia, Avenida André Araujo 2936, Bairro de Petrópolis. Caixa Postal 478, 69011-970 Manaus, Amazonas, Brazil. Email: vera@inpa.gov.br. phological level for some species (Coscarón, 1990; PyDaniel and Sampaio, 1995; Crosskey and Howard, 1997; Shelley et al., 1997; Hamada and Adler, 1999). Currently, this species group is composed of seven species: Simulium perflavum Roubaud 1906, Simulium maroniense Floch and Abonnenc 1946, Simulium rorotaense Floch and Abonnenc 1946, Simulium kabanayense Ramírez Pérez and Vulcano 1976, Simulium ignacioi Ramírez Pérez and Vulcano 1977, Simulium suarezi Ramírez Pérez, Rassi and Ramírez 1977 and Simulium trombetense Hamada, Py-Daniel and Adler 1999, based on the chromosomal, morphological and ecological evidence (Hamada, 1993, 1998; Hamada and Adler, 1998, 1999; Hamada and McCreadie, 1999; Alencar et al., 2001a, b).

Shelley et al. $(1984,1997)$ placed S. maroniense, formerly considered a good species by Coscarón (1990), and $S$. ignacioi in synonymy with $S$. rorotaense. Later, Hamada and Adler $(1998,1999)$ showed that $S$. rorotaense and $S$. maroniense can be distinguished at the morphological, cytotaxonomic and ecological levels and that S. ignacioi also has a distinct chromosomal configuration (N. Hamada, P.H. Adler and M.E. Grillet, unpublished data).

Based on polytene chromosome patterns, two groups of sister species were established for four species analyzed 
from this group: 1) $S$. perflavum and $S$. trombetense, which share one fixed inversion (IIIL-1) located in the terminal region of chromosome IIIL, and 2) $S$. maroniense and $S$. rorotaense, which share one fixed inversion (IIIL-5) also located in the terminal region of chromosome IIIL (Hamada and Adler, 1999). In addition, within the $S$. maroniense taxon four cytotypes were recognized, denominated A, B, C, and D (Hamada and Adler, 1999). Each cytotype has a different sex chromosome and different polymorphisms on the autosomal chromosomes, and each is associated with different environmental conditions such as landscape type, temperature, altitude, and geographical distribution. Cytotype A occurs in the rainforest on Mount Pacaraima, Roraima state (Brazil), cytotype B is represented by populations in savanna and forested areas in Roraima state (Brazil), cytotype C is found in Amapá and Pará states (Brazil), and cytotype D occurs in Amazonas state (Brazil). All cytotypes of $S$. maroniense can be distinguished from $S$. rorotaense by a fixed terminal inversion on the long arm of chromosome III (IIIL-5) and gill-histoblast morphology of last-instar larvae and pupae. In the present study, only $S$. maroniense cytotype D was included in the analyses.

In this study, we investigated the genetic variability and genetic divergence of populations of $S$. maroniense cytotype D, $S$. rorotaense, $S$. trombetense, and $S$. perflavum, based on isozyme electrophoresis, as an attempt to better understand the evolutionary relationships among these closely related species. This is the first study applying enzymatic markers to Simuliidae from Brazil.

\section{Material and Methods}

\section{Black-fly collection}

Black-fly specimens were collected in Presidente Figueredo and Manaus Counties, Amazonas state, Brazil. Simulium rorotaense was collected in Acará stream, Reserva Florestal Adolfo Ducke (02 ${ }^{\circ} 7^{\prime} \mathrm{S}$; 59 57' W), Manaus County. The other three species were collected in Presidente Figueiredo County: $S$. maroniense cytotype D in the Canoas stream ( $\left.01^{\circ} 49^{\prime} \mathrm{S} ; 60^{\circ} 04^{\prime} \mathrm{W}\right)$, BR-174 Highway $\mathrm{km} \mathrm{134;} \mathrm{S.} \mathrm{trombetense} \mathrm{in} \mathrm{the} \mathrm{Pantera} \mathrm{stream}\left(02^{\circ} 02^{\prime} \mathrm{S}\right.$; $\left.59^{\circ} 50^{\prime} \mathrm{W}\right), \mathrm{AM}-240$ Highway $\mathrm{km} 20$; and $S$. perflavum in the Escada stream $\left(02^{\circ} 02^{\prime} \mathrm{S}\right.$; 59 $52^{\prime}$ W), AM-240 Highway $\mathrm{km} 16$. Simulium maroniense, $S$. rorotaense and $S$. trombetense are found in larger, more shaded streams with substrates of boulders or bedrock, while $S$. perflavum occurs in smaller, slower, more open streams with sandy or pebble bottoms. The $S$. maroniense habitat has significantly higher $\mathrm{pH}$ than the habitats of the other three species.

Larvae were collected on all of the possible substrates in the streams, placed in Petri dishes with wet filter paper and maintained on ice until arrival in the laboratory at the Instituto Nacional de Pesquisas da Amazonia (INPA), Manaus, Amazonas. The last-instar larvae were identified according to Hamada and Adler (1998). Subsequently, they were placed in Eppendorf tubes, labeled and stored at $-70{ }^{\circ} \mathrm{C}$ until electrophoretic analyses.

\section{Isozyme electrophoresis}

Individual larvae of the four species were homogenized in $20 \mu \mathrm{L}$ of $0.5 \% \beta$-mercaptoethanol solution (v:v) on ice. The resulting suspensions were absorbed in Whatman number 3 papers, applied to the gels, and electrophoresed at $8^{\circ} \mathrm{C}$. The isozymes were analyzed using two types of electrophoresis horizontal supports: starch (12\%) and starch-agarose (2 and 0.8\%, respectively) gels (Scarpassa et al., 1999). Thirteen enzymes were tested (MDH, ME, PGM, ACON, IDH, GOT, PGI, XDH, EST, LAP, 6-PGD, $\mathrm{HK}$, and GDH). However, the three latter enzymes were not considered in the analyses due to their poor resolutions in the electrophoretic profiles, which did not allow accurate genotype counts. The enzyme systems, including symbol, Enzyme Commission number, and number of studied loci were: esterase (EST, E.C.3.1.1.1, 1 locus), leucine aminopeptidase (LAP, E.C.3.4.11.1, 2 loci), phosphoglucomutase (PGM, E.C.5.4.2.2, 1 locus), isocitrate dehydrogenase (IDH, E.C.1.1.1.42, 1 locus), aconitase (ACON, E.C.4.2.1.3, 1 locus), malate dehydrogenase (MDH, E.C.1.1.1.37, 1 locus), malic enzyme (ME, E.C.1.1.1.40, 1 locus), xanthine dehydrogenase (XDH, E.C.1.2.1.37, 1 locus), phosphoglucose isomerase (PGI, E.C.5.3.1.9, 1 locus), and glutamate-oxaloacetate transaminase (GOT, E.C.2.6.1.1, 1 locus). The buffer solutions and reaction mixtures were prepared according to Steiner and Joslyn (1979) and Scarpassa et al. (1999) with minor modifications.

\section{Statistical analysis}

Statistical analyses were performed using the Biosys-1 program (Swofford and Selander, 1989). Based on the allele frequencies, the genetic variability of each species was estimated using the mean number of alleles per locus (A), proportion of polymorphic loci (P), mean observed $\left(\mathrm{H}_{\mathrm{o}}\right)$ and expected $\left(\mathrm{H}_{\mathrm{e}}\right)$ heterozygosity, and test for conformance to Hardy-Weinberg equilibrium by chi-square analysis. The genetic relationship among species was measured by the Nei genetic distance values and dendrogram. Genetic distance (Nei, 1978) values were used to produce the dendrogram (Figure 1) based on the unweighted pair-group method using the arithmetic average (UPGMA). The no-criteria option from the Biosys-1 program was used to estimate the percentage of polymorphic loci. Thus, a locus was considered polymorphic regardless of the frequency of alleles detected. For each locus, the most frequent allele was designated as 100 and the other alleles numbered according to their mobility in relation to the most common allele. 
Genetic distance
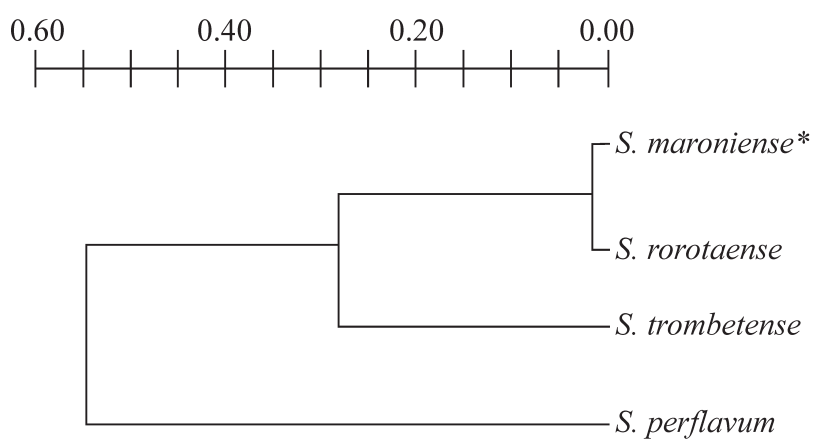

Figure 1 - Dendrogram of the Nei genetic distance among four species of the Simulium perflavum group, based on the UPGMA method. Cophenetic correlation $=0.996 . *$ Simulium maroniense cytotype D.

\section{Results}

The ten enzymes examined yielded 11 loci in the four species studied. All enzymes showed electronegative migration (anodic). Of the 11 loci, two (Lap-1 and Lap-2) were monomorphic for the same allele in the four species (Table 1). The remaining loci were either polymorphic for at least one of the species or were monomorphic within each species but had diagnostic alleles among the species, e.g., the $X d h$ and $M e$ loci. Table 1 shows sample size, allele frequency and Hardy-Weinberg equilibrium for each locus in the four species. Homogenous allelic frequencies were observed for 11 loci between $S$. maroniense and $S$. rorotaense. Consequently, none of the 11 loci was diagnostic between the two species; only the Pgi locus showed some evidence for differentiation in the most common allele $P g i{ }^{100}$ between $S$. maroniense $(0.825)$ and $S$. rorotaense (0.604). Simulium maroniense and $S$. rorotaense differed from $S$. trombetense by two diagnostic loci (Me and $X d h$ ), which were fixed for different alleles. $M e^{100}$ and $X d h^{100}$ alleles were fixed in $S$. maroniense and $S$. rorotaense, whereas the $M e^{103}$ and $X d h^{98}$ alleles were fixed in $S$. trombetense. Simulium perflavum differed from $S$. maroniense, $S$. rorotaense and $S$. trombetense by four diagnostic loci ( $M e, X d h, M d h$, and Got). The chi-square test applied to the Hardy-Weinberg model showed that most loci were in equilibrium (Table 1). However, two loci out of 19 comparisons $(10.5 \%)$ showed significant deviations from the expected Hardy-Weinberg equilibrium, due to deficiency of heterozygote individuals for the Pgm and Got loci in $S$. maroniense and $S$. trombetense, respectively. Three-banded heterozygotes were stained in four enzymes (MDH, IDH, GOT, and PGI), indicating a dimeric structure for these enzymes, and three enzymes (ACON, PGM, and EST) showed two bands in the heterozygotes, a pattern typical of monomeric enzymes. The enzymes ME, XDH, and LAP were monomorphic within each species (i.e. no heterozygote individual was detected). Therefore, it was not possible to know the structures of these proteins in the studied species.

Table 1 - Allele frequencies in four species of the Simulium perflavum species group.

\begin{tabular}{|c|c|c|c|c|c|}
\hline \multirow[t]{2}{*}{ Locus } & \multirow[t]{2}{*}{ Allele } & \multicolumn{4}{|c|}{ Species } \\
\hline & & S. maroniense* & S. rorotaense & S. trombetense & S. perflavum \\
\hline \multirow[t]{7}{*}{$M d h$} & $\mathrm{n}$ & 67 & 51 & 36 & 31 \\
\hline & 113 & $0.022^{b}$ & 0.000 & 0.000 & 0.000 \\
\hline & 109 & 0.000 & 0.000 & 0.000 & $1.000^{b}$ \\
\hline & 105 & $0.097^{b}$ & 0.000 & 0.000 & 0.000 \\
\hline & 100 & $0.873^{b}$ & $0.990^{b}$ & $0.972^{b}$ & 0.000 \\
\hline & 96 & 0.000 & $0.010^{b}$ & 0.000 & 0.000 \\
\hline & 91 & $0.007^{b}$ & 0.000 & $0.028^{b}$ & 0.000 \\
\hline$\chi_{\mathrm{H}-\mathrm{W}}^{2}{ }^{a}$ & & 4.45 & 0.00 & 0.01 & \\
\hline \multirow[t]{5}{*}{ Acon } & $\mathrm{n}$ & 20 & 20 & 24 & 24 \\
\hline & 105 & 0.000 & 0.000 & 0.021 & 0.000 \\
\hline & 103 & 0.000 & 0.000 & 0.104 & 0.000 \\
\hline & 102 & 0.100 & 0.000 & 0.000 & 0.000 \\
\hline & 100 & 0.900 & 1.000 & 0.875 & 1.000 \\
\hline$\chi_{\mathrm{H}-\mathrm{W}}^{2}$ & & 0.18 & & 0.40 & \\
\hline \multirow[t]{4}{*}{$\mathrm{Me}$} & $\mathrm{n}$ & 21 & 19 & 18 & 25 \\
\hline & 118 & 0.000 & 0.000 & 0.000 & $1.000^{b}$ \\
\hline & 103 & 0.000 & 0.000 & $1.000^{b}$ & 0.000 \\
\hline & 100 & $1.000^{b}$ & $1.000^{b}$ & 0.000 & 0.000 \\
\hline
\end{tabular}


Table 1 (cont.)

\begin{tabular}{|c|c|c|c|c|c|}
\hline \multirow[t]{2}{*}{ Locus } & \multirow[t]{2}{*}{ Allele } & \multicolumn{4}{|c|}{ Species } \\
\hline & & S. maroniense ${ }^{*}$ & S. rorotaense & S. trombetense & S. perflavum \\
\hline \multirow[t]{5}{*}{$P g m$} & $\mathrm{n}$ & 57 & 28 & 41 & 32 \\
\hline & 102 & 0.035 & 0.143 & 0.049 & 0.422 \\
\hline & 100 & 0.860 & 0.786 & 0.915 & 0.578 \\
\hline & 97 & 0.061 & 0.054 & 0.037 & 0.000 \\
\hline & 94 & 0.044 & 0.018 & 0.000 & 0.000 \\
\hline$\chi_{\mathrm{H}-\mathrm{W}}^{2}$ & & $17.11^{* * *}(\mathrm{df}=6)$ & 1.88 & 0.30 & 1.07 \\
\hline \multirow[t]{3}{*}{$I d h$} & $\mathrm{n}$ & 53 & 37 & 27 & 23 \\
\hline & 108 & 0.019 & 0.000 & 0.000 & 0.000 \\
\hline & 100 & 0.981 & 1.000 & 1.000 & 1.000 \\
\hline$\chi_{\mathrm{H}-\mathrm{W}}^{2}$ & & 0.01 & & & \\
\hline \multirow[t]{5}{*}{ Got } & $\mathrm{n}$ & 47 & 36 & 47 & 22 \\
\hline & 117 & $0.011^{b}$ & 0.000 & 0.000 & 0.000 \\
\hline & $\begin{array}{l}106 \\
100\end{array}$ & $\begin{array}{l}0.000 \\
0.968^{b}\end{array}$ & $\begin{array}{l}0.181^{b} \\
0.819^{b}\end{array}$ & $\begin{array}{l}0.032^{b} \\
0.936^{b}\end{array}$ & $\begin{array}{l}0.000 \\
0.000\end{array}$ \\
\hline & 94 & $0.021^{b}$ & 0.000 & $0.032^{b}$ & 0.000 \\
\hline & 89 & 0.000 & 0.000 & 0.000 & $1.000^{b}$ \\
\hline$\chi_{\mathrm{H}-\mathrm{W}}^{2}$ & & 0.03 & 0.01 & $30.38^{* * * *}(\mathrm{df}=3)$ & \\
\hline \multirow[t]{5}{*}{$P g i$} & $\mathrm{n}$ & 60 & 48 & 63 & 23 \\
\hline & 106 & 0.025 & 0.021 & 0.016 & 0.152 \\
\hline & 100 & 0.825 & 0.604 & 0.968 & 0.261 \\
\hline & 93 & 0.133 & 0.375 & 0.016 & 0.587 \\
\hline & 88 & 0.017 & 0.000 & 0.000 & 0.000 \\
\hline$\chi_{\mathrm{H}-\mathrm{W}}^{2}$ & & 2.55 & 0.96 & 0.05 & 6.08 \\
\hline \multirow[t]{4}{*}{$X d h$} & $\mathrm{n}$ & 19 & 20 & 27 & 44 \\
\hline & 102 & 0.000 & 0.000 & 0.000 & $1.000^{b}$ \\
\hline & 100 & $1.000^{b}$ & $1.000^{b}$ & 0.000 & 0.000 \\
\hline & 98 & 0.000 & 0.000 & $1.000^{b}$ & 0.000 \\
\hline \multirow[t]{3}{*}{ Est } & $\mathrm{n}$ & 53 & 33 & 36 & 20 \\
\hline & 100 & 0.962 & 1.000 & 0.972 & 1.000 \\
\hline & 98 & 0.038 & 0.000 & 0.028 & 0.000 \\
\hline$\chi_{\mathrm{H}-\mathrm{W}}^{2}$ & & 0.06 & & 0.01 & \\
\hline \multirow[t]{2}{*}{ Lap-1 } & $\mathrm{n}$ & 26 & 20 & 27 & 31 \\
\hline & 100 & 1.000 & 1.000 & 1.000 & 1.000 \\
\hline \multirow[t]{2}{*}{ Lap-2 } & $\mathrm{n}$ & 31 & 25 & 33 & 31 \\
\hline & 100 & 1.000 & 1.000 & 1.000 & 1.000 \\
\hline
\end{tabular}

* Simulium maroniense cytotype D. $\mathrm{df}=$ degree freedom.

${ }^{a}$ Chi-square for Hardy-Weinberg Equilibrium; ${ }^{* * *} \mathrm{p}<0.0001$.

${ }^{b}$ Diagnostic alleles.

The measures of genetic variability (Table 2 ) showed that the mean \pm SE number of alleles per locus ranged from $1.30 \pm 0.20$ to $2.30 \pm 0.40$; the lowest value was for $S$. perflavum and the highest value for S. maroniense. The percentage of polymorphic loci ranged from 18.2 to $63.6 \%$, with the lowest and the highest values for S. perflavum and $S$. maroniense, respectively. The mean $\pm \mathrm{SE}$ heterozygosity observed ranged from $0.062 \pm 0.025$ to $0.108 \pm 0.056$, with the lowest value for $S$. trombetense and the highest for $S$. rorotaense and $S$. maroniense. The latter two species had similar values for this measure.

Table 3 shows the values for similarity and genetic distance (above and below the diagonal, respectively) among the species. The genetic distance between $S$. 
Table 2 - Measures of genetic variability in four species of the Simulium perflavum species group.

\begin{tabular}{|c|c|c|c|c|c|}
\hline \multirow[t]{2}{*}{ Species } & \multirow{2}{*}{$\begin{array}{l}\text { Mean sample } \\
\text { size per locus }\end{array}$} & \multirow{2}{*}{$\begin{array}{l}\text { Mean number of } \\
\text { alleles per locus (A) }\end{array}$} & \multirow{2}{*}{$\begin{array}{c}\text { Percentage of } \\
\text { polymorphic }^{a} \text { loci (P) }\end{array}$} & \multicolumn{2}{|c|}{ Mean heterozygosity } \\
\hline & & & & Observed $\left(\mathrm{H}_{\mathrm{o}}\right)$ & Expected $\left(\mathrm{H}_{\mathrm{e}}\right)$ \\
\hline S. maroniense* & 41.3 & $\begin{array}{c}2.3 \\
(0.4)^{b}\end{array}$ & 63.6 & $\begin{array}{c}0.101 \\
(0.035)\end{array}$ & $\begin{array}{c}0.104 \\
(0.035)\end{array}$ \\
\hline$S$. rorotaense & 30.6 & $\begin{array}{c}1.6 \\
(0.3)\end{array}$ & 36.4 & $\begin{array}{c}0.108 \\
(0.056)\end{array}$ & $\begin{array}{c}0.108 \\
(0.056)\end{array}$ \\
\hline S. trombetense & 34.5 & $\begin{array}{c}1.9 \\
(0.3)\end{array}$ & 54.5 & $\begin{array}{c}0.062 \\
(0.025)\end{array}$ & $\begin{array}{c}0.062 \\
(0.023)\end{array}$ \\
\hline S. perflavum & 27.8 & $\begin{array}{c}1.3 \\
(0.2)\end{array}$ & 18.2 & $\begin{array}{c}0.088 \\
(0.060)\end{array}$ & $\begin{array}{c}0.097 \\
(0.066)\end{array}$ \\
\hline
\end{tabular}

* Simulium maroniense cytotype D.

${ }^{a}$ A locus was considered polymorphic regardless of the frequency of the detected alleles.

${ }^{b}$ The values within parenthesis are patterns errors.

Table 3 - Matrix of similarity (above) and distance (below) in four species of the Simulium perflavum species group.

\begin{tabular}{lcccc}
\hline Species & maroniense* $^{*}$ & rorotaense & trombetense & perflavum \\
\hline S. maroniense* & - & 0.990 & 0.799 & 0.572 \\
S. rorotaense & 0.010 & - & 0.785 & 0.597 \\
S. trombetense & 0.225 & 0.242 & - & 0.559 \\
S. perflavum & 0.559 & 0.515 & 0.581 & - \\
\hline
\end{tabular}

* Simulium maroniense cytotype D.

maroniense and $S$. rorotaense was $0.010,0.559$ between $S$. perflavum and $S$. maroniense, 0.515 between $S$. perflavum and $S$. rorotaense, and 0.581 between $S$. perflavum and $S$. trombetense. Simulium trombetense is more closely related to $S$. maroniense and $S$. rorotaense than to $S$. perflavum ( $\mathrm{D}=0.225$ and 0.242 , respectively). The genetic distance dendrogram (Figure 1) based on UPGMA methods showed that $S$. maroniense and $S$. rorotaense are highly similar. Simulium perflavum is the most divergent species among the four species studied in the S. perflavum group.

\section{Discussion}

In the S. perflavum species group, the mean heterozygosity ranged from 0.062 to 0.108 , which was similar to average values found in invertebrates $(0.112 \pm 0.072)$ (Nevo, 1978) and in other Diptera $(0.115 \pm 0.009)$ (Graur, $1985)$, as well as being very similar to values found in mosquitoes, such as Toxorhynchites rutilus (Hilburn et al., 1984), Anopheles darlingi (Manguin et al., 1999), Anopheles nuneztovari (Scarpassa et al., 1999), and Aedes aegypti (Souza et al., 2000). Simulium maroniense had the highest values for the two indices of variability (A and P). Simulium maroniense and S. rorotaense showed the highest values for mean heterozygosity $\left(\mathrm{H}_{\mathrm{o}}\right.$ and $\left.\mathrm{H}_{\mathrm{e}}\right)$. Thus, the highest values for the three indices detected for S. maroniense may indicate a large population size with low probability of inbreeding, perhaps because populations of this species occupy a wide niche and/or because these populations are ex- posed to great environmental heterogeneity in the central Brazilian Amazon (McDonald and Ayala, 1974; Narang, 1980). Simulium perflavum showed the lowest values for the first two indices (A and P); however, this species did not have the lowest heterozygosity value. These results agree, partially, with those obtained by polytene chromosome analysis, where $S$. perflavum was almost monomorphic throughout the study area in Brazil and Venezuela (Hamada and Adler, 1999). Simulium perflavum is of specialist habitat and occupies a narrow niche (Hamada, 1993; Hamada and McCreadie, 1999), which may be reflected in the low levels of polymorphism indicated by izozymes and polytene chromosomes.

The isozyme markers used to estimate genetic relationships among the four species in the $S$. perflavum group suggest that these species are closely related (Distance $=0.010-0.581$ ). Similar genetic distance values were found among sibling species in the Simulium jenningsi complex: $\mathrm{D}=0.10-0.58$ (May et al., 1977). However, our values were higher than those observed among sibling species of the $S$. venustum and $S$. verecundum complexes: $\mathrm{D}=0.06-0.29$ (Snyder, 1982). In anophelines mosquitoes, the average genetic distance between pairs of sibling species is often between 0.10 and 0.30 (Bullini and Coluzzi, 1982). Values above this range have usually been found between species that already show some degree of morphological differentiation (Cianchi et al., 1981; Manguin et al., 1995; Dias-Rodrigues, 1998; Schaffner et al., 2000). In the Drosophila willistoni group, mean genetic distances for various stages of evolutionary divergence are as follows: between local populations 0.03 ; between subspecies 0.23 ; between sibling species 0.58 ; between non-sibling species 1.06 (Ayala et al., 1975). In the present study, the distance values found are closer to those obtained among sibling species in Simulium and Drosophila.

In the present study, the four species analyzed can be morphologically distinguished at the pupal stage. They therefore cannot be considered to be sibling species. Four diagnostic loci allowed separation of S. perflavum from the 
other three species, while two diagnostic loci distinguished $S$. trombetense from $S$. maroniense and $S$. rorotaense. Thus, $S$. perflavum is genetically well diverged from the other species. This conclusion agrees with the polytene chromosome data, where S. perflavum is the most divergent from the other species, with six fixed inversions. Although two diagnostic loci were found between $S$. trombetense and S. maroniense/S.rorotaense, the genetic distance values were low ( $\mathrm{D}=0.225-0.242$, similar to values found between sibling species of Simulium and Anopheles, and between subspecies of Drosophila). This result suggests that the morphological differences by which these species are well defined arose with little differentiation at the isozyme level. Interestingly, the polytene chromosome data indicated that $S$. trombetense is more closely related to $S$. perflavum than to $S$. maroniense and $S$. rorotaense. The discrepancy between chromosome and isozyme data could be explained by the IIIL-1 inversion that is fixed and shared in $S$. trombetense and S. perflavum, which is really part of the ground plan of the $S$. perflavum group, rather than a synapomorphy for these two species. If this is the case, $S$. trombetense, $S$. perflavum, and $S$. maroniense / $S$. rorotaense would be in an unresolved chromosomal trichotomy. On the other hand, analysis of additional isozyme loci may provide a better explanation for this distinctive result, but it has been difficult to identify many loci with good resolution in these Simulium species.

Diagnostic loci were not found between $S$. maroniense cytotype D and $S$. rorotaense, and the genetic distance was very low ( $\mathrm{D}=0.010)$. The level of heterozygosity was also similar between the two species. Of the 11 loci, only the Pgi locus appears to be in the process of differentiation. Similar distance values have frequently been observed among populations of same species (Ayala et al., 1975; Manguin et al., 1995; Scarpassa et al., 1999; Sukowati et al., 1999). Results somewhat similar to these of the present study have been obtained between sister taxa Prosimulium fuscum and P. mixtum. Of the 11 loci studied, only one $(6-P g d)$ allowed identification between the two Prosimulium species; the remaining loci showed similar allele frequencies and the monomorphic loci had identical alleles (Snyder and Linton, 1983). Low distance values have also been found between Drosophila heteroneura and $D$. silvestre (Sene and Carson, 1977) and among fossorial mole rats in the Spalax ehrenbergi complex (Nevo and Cleve, 1978), which were attributed to recent divergence. In the present study, the low genetic distance value and the absence of diagnostic loci should be interpreted cautiously because the three other $S$. maroniense cytotypes were not used for comparison with $S$. rorotaense, so that diagnostic loci might be found in these cytotypes, especially in the most divergent ones. At the morphological level, although these two species are isomorphic in the adult stage, the four $S$. maroniense cytotypes can be distringuished from $S$. rorotaense using gill-histoblast morphology of last-instar larvae and pupae and also by a fixed inversion on the long arm of chromosome III (IIIL-5), with a confidence level of $99.4 \%$. Alternatively, the examination of additional isozyme loci or other genetic markers that evolve faster, such as mtDNA (mitochondrial DNA) and highly variable loci (microsatellites), may permit better separation between the $S$. maroniense cytotype D and $S$. rorotaense. However, although the three other cytotypes were not used for comparison in this study, the high similarity found at the isozyme level, allied with previous data on morphology and cytotaxonomy, may indicate that the evolutionary divergence time since the separation of these two species is still very recent.

In summary, the genetic relationships suggested by the comparison of 11 isozyme loci in four species of the $S$. perflavum group indicate that these species are closely related. This result supports those from the external morphology data and agrees, at least in part, with the relationships established from polytene chromosome rearrangements. This is the first study applying enzymatic markers to Simuliidae in Brazil, and the results suggest that these markers can provide useful insights into the evolutionary history of this family.

\section{Acknowledgments}

This research was funded by MCT/INPA and CNPq. We thank Ana M. O. Pes, Jefferson O. Silva and João Bosco Lapa (INPA, Manaus, Brazil) for help in some of the field collections. We also thank Philip M. Fearnside (INPA, Manaus, Brazil) for revision on the manuscript.

\section{References}

Alencar YBA, Ludwig TAV, Soares CC and Hamada N (2001a) Stomach content analyses of Simulium perflavum Roubaud 1906 (Diptera: Simuliidae) larvae from streams in Central Amazonia, Brazil. Mem Inst Oswaldo Cruz 96:561-576.

Alencar YBA, Hamada N and Magni-Darwich S (2001b) Morphometric comparison of Simulium perflavum larvae (Diptera: Simuliidae) between season and gender in Central Amazonia, Brazil. Mem Inst Oswaldo Cruz 96:785-789.

Almeida FS and Sodré LMK (1998) Analysis of genetic variability in three species of Pimelodidae (Ostariophysi, Siluriformes). Genet Mol Biol 21:487-492.

Ayala FJ, Tracey ML, Hedgecock D and Richmond RC (1975) Genetic differentiation during the speciation process in Drosophila. Evolution 28:576-592.

Bullini L and Coluzzi M (1982) Evolutionary and taxonomic inferences of electrophoretic studies in mosquitoes. In: Steiner WWM, Tabachnick WJ, Rai KS and Narang S (eds) Recent Developments Genetics Insects Disease Vectors. Champaign, Stipes, IL, pp 465-482.

Charalambous M, Ready PD, Shelley AJ, Arzube M and Lowry CA (1993) Cytological and isoenzyme analysis of the Bucay and Quevedo cytotypes of the onchocerciasis vector Simulium exiguum (Diptera: Simuliidae) in Ecuador. Mem Inst Oswaldo Cruz 88:39-48. 
Cianchi R, Sabatini A and Coluzzi M (1981) Differenziazione morphologica e genetica nei complessi Anopheles maculipennis e Anopheles claviger. Parassitologia 23:158163.

Coscarón S (1990) Taxonomia y distribution del subgênero Simulium (Ectemnaspis) Enderlein (Simuliidae, Diptera, Insecta). Iheringia Séries Zoológica 70:109-170.

Crosskey RW and Howard TM (1997) A New Taxonomic and Geographical Inventory of World Blacflies (Diptera: Simuliidae). Natural History Museum, London.

Davies JB, Basanez MG, Frontado H, Villamizar N, Raybould JN and Petralanda I (2000) Phosphoglucomutase and trehalase isoenzymes of Venezuelan Simulium vectors of Onchocerca volvulus. Med Vet Entomol 14:321-331.

Dias-Rodrigues GA (1998) Padrões isoenzimáticos e variabilidade genética em Anopheles (Anopheles) intermedius Chagas, 1908 e Anopheles (A.) mattogrossensis Lutz \& Neiva, 1911 (Diptera: Culicidae) da Amazônia brasileira. MS Thesis, Instituto Nacional de Pesquisas da Amazônia/UA, Manaus, AM.

Farid HA, Gad AM and Spielman A (1991) Genetic similarity among Egyptian populations of Culex pipiens (Diptera: Culicidae). J Med Entomol 28:198-204.

Graur D (1985) Gene diversity in Hymenoptera. Evolution 39:190-199.

Hamada N (1993) Association between Hemerodromia sp. (Diptera, Empididae) and Simulium perflavum (Diptera, Simuliidae) in Central Amazonia, Brazil. Mem Inst Oswaldo Cruz 88:169-170.

Hamada N (1998) Bionomics of Simulium perflavum Roubaud (Diptera: Simuliidae) in Central Amazonia, Brazil. Rev Brasil Entomol 41:523-526.

Hamada N and Adler PH (1998) Taxonomy of the Simulium perflavum Species-Group (Diptera: Simuliidae), with description of a new species from Brazil. Insecta Mundi 12:207-226.

Hamada N and Adler PH (1999) Cytotaxonomy of four species in the Simulium perflavum Species-Group (Diptera: Simuliidae) from Brazilian Amazonia. Syst Entomol 24:273-288.

Hamada N and McCreadie JW (1999) Environmental factors associated with the distribution of Simulium perflavum (Diptera: Simuliidae) among streams in Brazilian Amazonia. Hydrobiologia 397:71-78.

Hilburn LR, Willis NL and Seawright JA (1984) An electrophoretic comparison of laboratory colonies and natural populations of four species of Toxorhynchites (Diptera: Culicidae). J Med Entomol 21:336-343.

Krafsur ES, Nariboli P and Tollefson JJ (1993) Gene diversity in natural Diabrotica barberi Smith \& Lawrence populations (Coleoptera: Chrysomelidae). Ann Entomol Soc 86:490496.

Kreutzer RD, Palau MT, Morales A, Ferro C, Feliciangeli D and Young DG (1990) Genetic relationships among phlebotomine sand flies (Diptera: Psychodidae) in the verrucarum species group. J Med Entomol 27:1-8.

Lopes G and Moreno J (1995) Genetic variability and differentiation between populations of Rhodnius prolixus and $R$. pallescens, vectors of Chagas's disease in Colombia. Mem Inst Oswaldo Cruz 90:353-357.
Manguin S, Roberts DR, Peyton EL, Fernandes-Salas I, Barreto M, Fernandez Loayza R, Elgueta Spinola R, Martinez Granaou R and Rodrigues MH (1995) Biochemical systematics and population genetics of Anopheles pseudopunctipennis, vector of malaria in Central and South America. Am J Trop Med Hyg 53:362-377.

Manguin S, Wilkerson RC, Conn JE, Rubio-Palis Y, Danoff-Burg JA and Roberts D (1999) Population structure of the primary malaria vector in South America, Anopheles darlingi, using isozyme, random amplied polymorphic DNA, internal transcribed spacer 2, and morphologic markers. Am J Trop Med Hyg 60:364-376.

May B, Bauer LS, Vadas RL and Granett J (1977) Biochemical genetic variation in the family Simuliidae electrophoretic identification of the human biter in the isomorphic Simulium jenningsi group. Ann Entomol Soc Am 70:637-640.

McDonald JF and Ayala FJ (1974) Genetic response to environmental heterogeneity. Nature 250:572-574.

Mebrahtu Y, Beach RF, Hendricks LD and Oster CN (1987) Isozyme variation in Simulium (Edwardsellum) damnosum s.1. (Diptera: Simuliidae) from Kenya. J Am Mosquito Control Assoc 3:196-200.

Narang SK (1980) Genetic variability in natural populations, evidence in support of the selectionist view. Experientia 36:50-51.

Nei M (1978) Estimation of average heterozygosity and genetic distance from a small number of individuals. Genetics 89:583-590.

Nevo E (1978) Genetic variation in natural populations: patterns and theory. Theory Pop Biol 13:121-177.

Nevo E and Cleve H (1978) Genetic differentiation during speciation. Nature 275:125-126.

Petersen JL (1982) Population genetics of some New World Simuliidae. In: Steiner WWM, Tabachnick WJ, Rai KS and Narang S (eds) Recent Developments Genetics Insects Disease Vectors. Champaign, Stipes, IL, pp 628-642.

Py-Daniel V and Sampaio RTM (1995) Gêneros e espécies de Simuliidae (Diptera: Culicomorpha) assinalados para o Brasil até 1995. Entomologia y Vetores 2:117-121.

Scarpassa VM, Tadei WP and Suarez MF (1999) Population structure and genetic divergence in Anopheles nuneztovari (Diptera: Culicidae) from Brazil and Colombia. Am J Trop Med Hyg 60:1010-1018.

Schaffner F, Raymond M and Pasteur N (2000) Genetic differentiation of Anopheles claviger s.s. in France and neighbouring countries. Med Vet Entomol 14:264-271.

Sene FM and Carson HL (1977) Genetic variation in Hawaiian Drosophila. IV. Close allozymic similarity between $D$. silvestris and D. heteroneura from the island of Hawaii. Genetics 86:187-198.

Shelley AJ, Luna Dias APA and Maia-Herzog M (1984) New specific synonymy in Neotropical Simulium s.l. (Diptera: Simuliidae). Mem Inst Oswaldo Cruz 79:143-161.

Shelley AJ, Lowry CA, Maia-Herzog M, Luna Dias APA and Moraes MAP (1997) Biosystematic studies on the Simuliidae (Diptera) of the Amazonia onchocerciais focus. Bull Nat History Museum London (Ent) 66:1-121.

Snyder TP (1982) Electrophoretic characterizations of black flies in the Simulium venustum and verecundum species complexes (Diptera: Simuliidae). Can Ent 114:503-507. 
Snyder TP and Linton MC (1983) Electrophoretic and morphological separation of Prosimulium fuscum and P. mixtum larvae (Diptera: Simuliidae). Can Ent 115:81-87.

Souza GB, Avilés G and Gardenal CN (2000) Allozymic polymorphism in Aedes aegypti populaitons from Argentina. J Am Mosquito Control Assoc 16:206-209.

Steiner WWM and Joslyn, DJ (1979) Electrophoretic techniques for the genetic study of mosquitoes. Mosq News 39:35-54.

Steiner WWM, Narang S, Kitzmiller JB and Swofford DL (1982) Genetic divergence and evolution in neotropical Anopheles (subgenus Nyssorhynchus). In: Steiner WWM, Tabachnick WJ, Rai KS and Narang S (eds) Recent Developments Genetics Insects Disease Vectors. Champaign, Stipes, IL, pp 523-551.
Sukowati S, Baimai V, Harun S, Dasuki Y, Andris H and Efriwati M (1999) Isozyme evidence for three sibling species in the Anopheles sundaicus complex from Indonesia. Med Vet Entomol 13:408-414.

Swofford DL and Selander RB (1989) BIOSYS-1. A Computer Program for the Analysis of Allelic Variation in Population Genetics and Biochemical Systematics. Release 1.7. Champaign, IL: Illinois Natural History Survey.

Tabachnick WJ (1992) Microgeographic and temporal genetic variation in populations of the bluetongue virus vector Culicoides variipennis (Diptera: Ceratopogonidae). J Med Entomol 29:384-394.

Associate Editor: João S. Morgante and Louis Bernard Klaczko 